\title{
A systematic review of wastewater monitoring and its applications in urban drainage systems
}

Una revisión sistemática del monitoreo de Aguas Residuales y sus aplicaciones en sistemas de drenaje urbano

Carlos Alexis Bonilla-Granados ${ }^{1 *}$, Juan Camilo Barrera-Triviño ${ }^{2}$, Gonzalo Cifuentes-Ospina ${ }^{3}$

I* Master in Water and Waste Management Technologies, carlosalexisbg@ufps.edu.co, ORCID: 0000-0002-4558-4615, Universidad Manuela Beltrán, Colombia.

2 Master in Civil Engineering, Hydrology, Water Resources and Hydroinformatics, camilo.barrera@docentes.umb.edu.co, ORCID: 0000-0003-0928-7338, Universidad Manuela Beltrán, Colombia.

3 Master in Civil Engineering, Hydrology, Water Resources and Hydroinformatics, gonzalo.cifuentes@docentes.umb.edu.co, ORCID: 0000-0003-0024-645X, Universidad Manuela Beltrán, Colombia.

How to cite: C. Bonilla-Granados, J. Barrera-Triviño and G. Cifuentes-Ospina, "A systematic review of wastewater monitoring and its applications in urban drainage systems”. Respuestas, vol. 24, no. 3, pp. 53-62, 2019.

Received on February 23, 2018 - Approved on June 18, 2018

\begin{tabular}{ll}
\hline KBSTRACT \\
\hline Keywords: & $\begin{array}{l}\text { Urban drainage systems have an important role in the planning and development of cities, they } \\
\text { allow a good management of the wastewater flow, and their study is important to understand the } \\
\text { physicochemical characteristics of water and the relationships between the maximum flows and }\end{array}$ \\
Wastewater, & means of each system. This is a review of wastewater monitoring and their applications, which \\
Maximum peak & is done through the consultation of databases and other documentary sources of free access like \\
factor, & scientific journals. The research strategy was based on 3 thematic axes that were: monitoring \\
Monitoring, & of wastewater, obtaining parameters of the system and network management. We reviewed 69 \\
Urban drainage & references of different countries around the world countries and we focused in the methodologies \\
systems. & used in each study case. In conclusion, we highlight the importance of implementation of measure \\
& instruments, monitoring and control systems.
\end{tabular}

\section{RESUMEN}

\section{Palabras clave:}

Los sistemas de drenaje urbano juegan un papel importante en la planeación y el desarrollo de las ciudades, siendo primordial conocer el funcionamiento del flujo de aguas residuales, sus

Aguas residuales, Factor máximo de características fisicoquímicas y las relaciones existentes entre los caudales máximos y medios de cada sistema. Este artículo proporciona una revisión del monitoreo de aguas residuales y sus pico,

Monitoreo, aplicaciones, la cual se realizó a través de la consulta de bases de datos especializadas y otras fuentes documentales de revistas científicas de acceso abierto en diversos países. Se estableció Sistemas de drenaje urbano. una estrategia de búsqueda en torno a 3 ejes temáticos que fueron: monitoreo de aguas residuales, obtención de parámetros propios de cada sistema y la gestión de redes. Se revisaron 69 referencias que permitieron identificar cuáles son los países que más investigan sobre el tema y cuales han sido las metodologías empleadas en cada caso de estudio. En conclusión, se sugiere como tema de investigación implementar sistemas de instrumentación, monitoreo y control, que permitan un adecuado y permanente control de los sistemas de drenaje en Colombia debido al poco número de número de investigaciones desarrolladas en el país.

\section{Introduction}

The evacuation of wastewater has been a constant problem in human organizations since the beginning of civilizations, initially the waste discharged into the receiving bodies did not pose a problem of great magnitude, but over time several factors were added that impacted on the increase in quantity and degradation of the water waste water produced. Among the most relevant factors were the permanent location of communities, the increase in population, the industrial revolution, the advance of the chemical industry, among others. The growth in the flow of

*Corresponding author:

E-mail address: carlosalexisbg@ufps.edu.co (Carlos Alexis Bonilla Granados)

(c) (1) $\Theta$ Peer review is the responsibility of the Universidad Francisco de Paula Santander

This is an article under the license CC BY-ND (http://creativecommons.org/licenses/by-nc-nd/4.0/) 
wastewater produced in urban centers brought with it consequences such as the proliferation of diseases, the decomposition of solid waste and later the permanent deterioration of water bodies near cities, thus showing the obvious lack of planning in the original conception of cities to evacuate waste and wastewater generated [1].

Based on these considerations, it is worth highlighting the role played by sanitary engineering throughout history in wastewater management, resulting in the implementation of urban drainage systems as a solution to the latent problem, promoting means of collection capable of removing waste as quickly as possible from existing populations. These systems have played a very important role in the development and growth of cities, having direct implications on people's quality of life, as they are necessary to collect and treat wastewater in order to avoid pollution of receiving water bodies and public health problems [1].

These systems should be designed based on existing information or field measurements that take into account consumption patterns and the characteristics of each locality; in the absence of information, these factors should be estimated with approximate empirical equations [2]. The use of these approximate equations or traditional formulas to calculate these factors, such as the maximum peak factor, may lead to over-dimensioning of network pipelines in some cases, especially in small cities [3].

The reliable estimation of these flows is essential to guarantee adequate planning and optimal operation of complementary components such as wastewater pumping stations and the different elements of treatment plants, whose design is based on the critical flows presented, whether maximum or minimum, which in turn are directly related to the size of the community and socioeconomic conditions [4], therefore today it is essential to implement instrumentation, monitoring and control systems that allow adequate and permanent control of the quality of service of urban drainage systems [2].

The monitoring of wastewater becomes an important element to ensure universal access to safe drinking water, by controlling the quantity and quality of discharges generated on surface water bodies, therefore, it is necessary to make adequate investments in infrastructure and sanitation facilities such as urban drainage systems [5].

This article develops a review of several case studies of wastewater monitoring and its relationship to identify and control parameters specific to each drainage system, as well as different methodologies used in the management of networks that allowed to identify damage, problems such as overflow and obstruction and also the characterization and control of various parameters of quality of discharged water.

\section{Wastewater Monitoring}

At present, wastewater monitoring has become an important topic of scientific research worldwide, by consulting on this subject in databases of scientific information and other sources of open access scientific journals could be found to be a universal theme developed in countries of five continents. Table 1 shows the countries with the most wastewater monitoring research between 2017 and 2019.

Table I. Empirical formulas of population-dependent peak factor

\begin{tabular}{|c|c|c|}
\hline Articles & Country & Reference \\
\hline 13 & China & {$[6][7][8][9][10][11][12][13][14][14][15][16][17]$} \\
\hline 9 & USA & {$[18][19][20][21][22][23][24][25][26]$} \\
\hline 7 & Finland & {$[27][28][29][30][31][32][33]$} \\
\hline 6 & Australia & {$[34][35][36][37][38][39]$} \\
\hline 5 & Brazil & {$[40][41][42][43][44]$} \\
\hline
\end{tabular}

From table 1 it can be seen that Asia, with China leading the research on wastewater monitoring, on the other hand, America is represented by USA and Brazil, as well as Europe by Finland. No articles developed in Colombia were observed in this search, although some research found in other databases will be mentioned later.

\section{Objectives of monitoring activities}

Since urban drainage systems such as sanitary sewers are in operation, they can be useful for evaluating and managing the performance of the system and planning its development. For this purpose, it is necessary to implement actions that allow monitoring the behavior of the flow in the networks, which in turn becomes one of the main impediments in most cases, due to the costs involved in computer and data management. These constraints are most noticeable 
in cities in developing countries, where watersheds can be large, data tend to be scarce, and there are many unknowns about the functioning system [45].

Wastewater flow monitoring identifies variables that must be measured in order to be useful for future designs [46] and is of great importance for their maintenance and operation, since it gives us an immediate view of what is happening in the drainage area under study [47]. Implementing these monitoring actions effectively shows the oscillations in the wastewater discharge flow with respect to time [48], some of the variations we can distinguish are:

\section{Annual and monthly monitoring}

In the summer months, water consumption is higher due to the high temperatures presented, which is reflected in greater contributions to the sewerage networks and in the months of greater precipitation there may be peaks in the variation of the flow, originated by erroneous connections in the system, as well as in tourist sites there are great variations throughout a year in the evacuation of sewage, as well as there are seasonal industries that only consume water during a part of the year. An example of this variation is shown in figure 1 where the annual variation in the Pine Valley, Baltimore, USA, is observed [49].

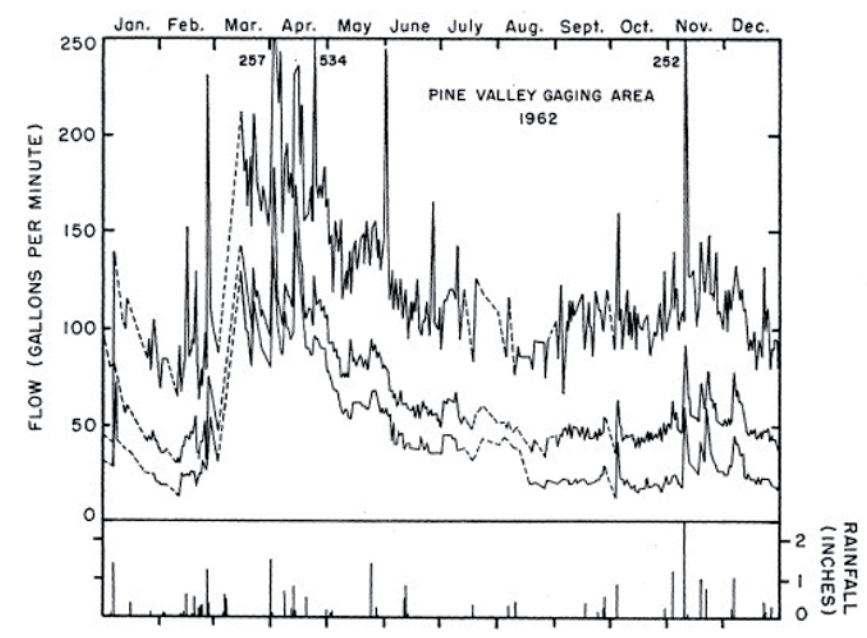

Figure 1. Annual variation, precipitation and maximum, average and minimum sewer flow Source: [49]

\section{Weekly and daily measurements}

There are days in the week in which more water is consumed and in some industries that do not function during the weekend, in view of these particularities, the changes in the quantity of wastewater contributed weekly to the sanitary sewer are appreciable. The daily variations are a faithful reflection of the activity of the population of a determined place, during the night and first hours of the day, the flows of residual waters are minimum, being these flows composed fundamentally by infiltrated waters and by small quantities of domestic residual waters, an example of this is observed in figure 2 , where the comparison of the variation of the flow of residual waters in 25 different days in the commune Puente Alto in the city of Santiago, Chile is shown [50].

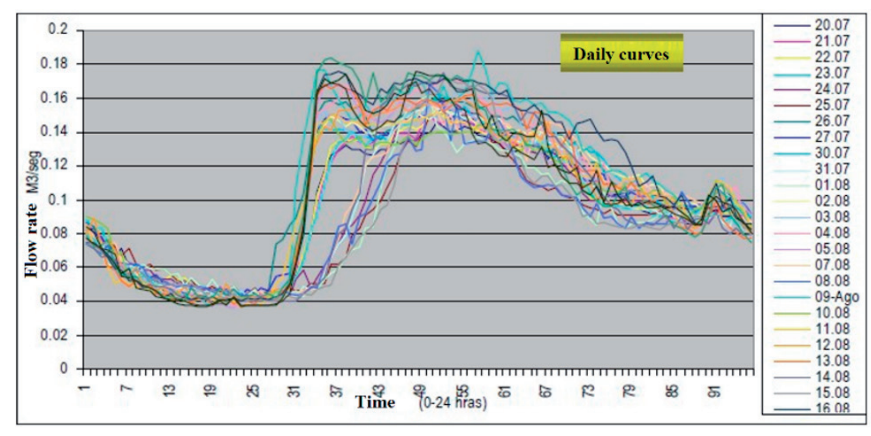

Figure 2. Daily variation in wastewater fl ow Source: [51]

The monitoring of wastewater in urban drainage systems has had different fi elds of research, in this review will be a description of research developed in obtaining own parameters and management of drainage systems.

\section{Obtaining the system's own parameters}

In addition to wastewater fl ow monitoring, research has also been carried out to determine the average and maximum hourly fl ow values of a given population. To begin with, we have the example of a study carried out on the island of Malta, an island country located in the Mediterranean Sea to the south of Italy; a study in which the drainage department of the Maltese Ministry of the Environment, together with the Civil Engineering department of the Imperial College of Science, Technology and Medicine, carried out a master plan idealised for the conception of a series of projects such as the use of maximum fl ows of rainwater, the rehabilitation and maintenance of existing sewers (built more than a 
century ago), the construction of new wastewater treatment plants and final outfalls, in order to cover the demands generated up to the year 2010 and to be able to quantify the real variations of wastewater flows in dry and wet weather and to be able to quantify the real variations of wastewater flows in dry and wet weather [52].

In order to be able to quantify these volumes, a study was carried out in 51 households on the Malta Island. This selection was made on the basis of statistics that allowed a reasonable representation of the locality to be obtained, and a monitoring methodology called "Synthesising dry weather flow input hydrographs: a maltese case study" could be established: which allowed to determine the hydrogram of incoming flow in dry time or curve of hourly variation of waste water flow, in which the behavior of the flows in the system was identified finding the hour of maximum consumption at 8:00 am with a value of 233 liters/person/day and an average flow of 95 liters/person/day [52].

Another case study was carried out in Eindhoven in the Netherlands. Long-term, 19-month, high-frequency monitoring was implemented in the sewage system to study water quantity and variations in water quality, carrying out flow monitoring campaigns in dry weather for approximately 160 days and in wet weather situations for approximately 40 storms, this research was carried out in three different areas of the system. For dry weather, a diurnal variation in wastewater flow was observed for the three catchment areas studied, but in turn at peak discharge times, flows are usually normally distributed. In terms of wastewater quality in two catchment areas, contaminant concentrations show a diurnal variation similar to the flow, contrary to the other area in which it causes a diurnal variation of contaminant concentrations very different from the others [53].

One of these approaches is the real calculation of the maximum peak factor for the design of sanitary sewerage systems, whether designed and constructed for the first time or built as part of an existing system, in these cases being able to determine the real value of this factor of increased flow has become an important concern.

\section{Maximum peak factor and Maximum hourly wastewater flow rate}

The variation in wastewater flows can be measured or quantified by means of a coefficient called the maximum peak factor, $\mathrm{F}$, which takes into account the variations in water consumption by the population and must be interpreted in a probabilistic sense, due to the uncertainty that exists in the magnitudes of the maximum and mean flows, is determined through empirically established expressions, derived from the combination of field measurements and the engineering criterion [54]. In other words, this factor makes it possible to increase the average daily flow in order to establish the peak wastewater flow or maximum hourly flow, which is defined as the maximum hourly flow of the day of maximum consumption, and is the basis for establishing the design flow of each of the sections of a wastewater sewerage network and is calculated according to (1) [46].

$$
Q M H=Q m d^{*} F P
$$

Where:

$Q M H$ is the maximum hourly flow rate $\left(\mathrm{m}^{3} / \mathrm{h}\right.$ o $\left.\mathrm{L} / \mathrm{s}\right)$ Qmd is the average daily flow rate $\left(\mathrm{m}^{3} / \mathrm{h}\right.$ o $\left.\mathrm{L} / \mathrm{s}\right)$ FP is the maximum peak factor. $\left(\mathrm{m}^{3} / \mathrm{h}\right.$ o $\left.\mathrm{L} / \mathrm{s}\right)$

In sewerage systems, it is essential to have appropriate methodologies to quantify variations in the flow generated in certain periods of time [45], especially when there are parameters that can greatly affect the hydraulic design of collector networks and treatment plants, it is therefore necessary to analyse in detail, on the basis of the available data, the variations in the flow rate [55]. In populations that do not have field wastewater flow monitoring, several equations have been developed to estimate flow factors. The common variables governing most of these equations are population and average daily flow [4]. Some of the most common population-dependent peak factor calculation methods are shown in Table II [56]. 
Table II. Population-dependent peak factor empirical formulas

\begin{tabular}{|c|c|}
\hline $\begin{array}{c}\text { Peak Factor } \\
\text { Formula }\end{array}$ & Conditions of application \\
\hline $\begin{array}{l}\mathrm{FP}=1+\frac{14}{\left(4+\mathrm{P}^{0.5}\right)} \\
\text { FP de Harmon.[57]. }\end{array}$ & $\begin{array}{c}\mathrm{P} \text { en miles } \\
\mathrm{P}<1^{\prime} 000.000 \text { habitantes. }\end{array}$ \\
\hline $\begin{array}{l}\mathrm{FP}=\frac{5}{\left(\frac{\mathrm{P}}{1000}\right)^{0.167}} \\
\text { FP de Babbit. [58]. }\end{array}$ & $10.000<\mathrm{P}<10^{\prime} 000.000$ \\
\hline $\begin{array}{c}F P=\frac{14}{P^{0.1667}} \\
\text { FP de Gifft.[59]. }\end{array}$ & $\begin{array}{l}\text { FP Máximo }=3.0 \\
\text { FP Mínimo }=1.6\end{array}$ \\
\hline $\begin{array}{c}\text { Para } \mathrm{P}<5000, \mathrm{FP}=4 \\
\text { Para } 5000<\mathrm{P}<1000000, \mathrm{FP}=7.7-\log \mathrm{P} \\
\text { FP de Metcalf \& Eddy.[55]. }\end{array}$ & $\begin{array}{l}\text { FP Máximo }=4.0 \\
\text { PF Mínimo }=1.7\end{array}$ \\
\hline
\end{tabular}

In turn, there are equations for calculating the maximum peak factor as a function of average flow or average wastewater flow rate, which were calculated with available flow records. Some examples are presented in Table III.

Table III. Empirical formulas of peak factor depending on average flow rate

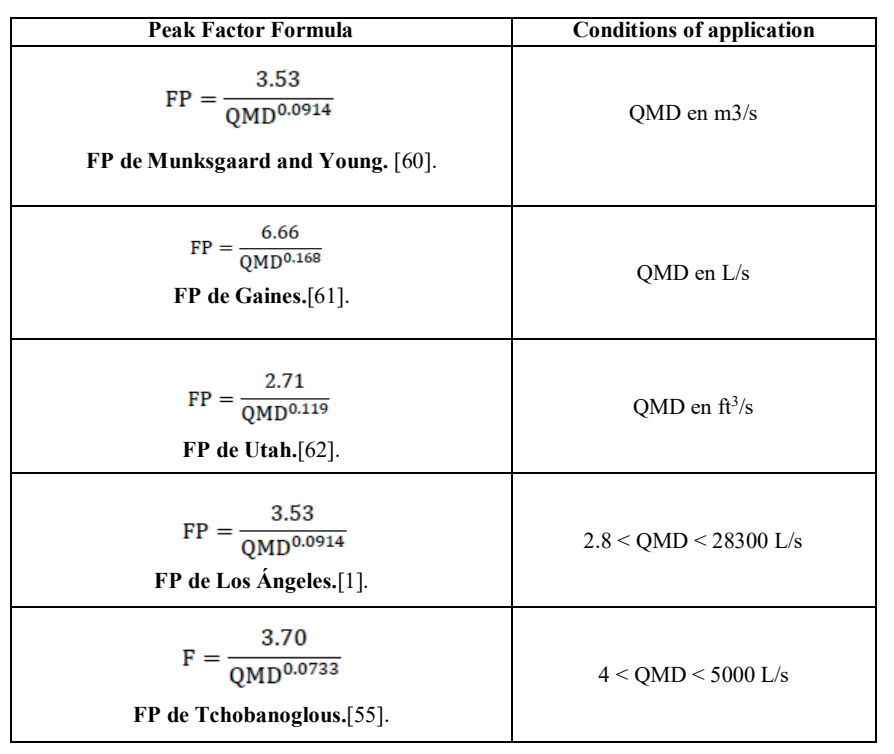

These equations were the result of structured investigations by each author in the drainage systems of each locality in which it was desired to analyze the behavior of the flows contributed to each system, for example in 1999 in the state of Utah, United States, Brigham Young University through the College of Engineering and Technology carried out research to develop a tentative equation of the peak factor and thus be able to use this equation in the calculation of the maximum flow of wastewater in the designs of sewage systems, for the development of this proposal eight years of flow data were analyzed for four cities in the state which were Orem, Provo, Spanish Fork and Spring City, it was possible to determine a maximum peak factor equation that could be used in Utah and similar regions. As a result of this research it could be established that the relationships developed with the new equation are very close to the values given by the Los Angeles equation [1], but significantly lower than the oldest values used in the United States, the final result was the equation shown in Table III, named Utah peak factor equation [62].

Studies have also been carried out in other parts of the Americas in order to evaluate this problem of the uncertainty of the maximum peak factor, in the city of Managua, by means of hydraulic gauging, in a period of four weeks, in the collectors of the sanitary sewer networks of four colonies, which were: Colonia Independencia, Colonia Centroamérica, Belmonte and Casa Real; then, to apply a mathematical method to obtain the coefficient in question. As a result, we found the following peak factors obtained for each locality as well: Colonia Independencia obtained two values, a first value of $\mathrm{F}=2.3$ and a second value of $\mathrm{F}=3.4$, Colonia Centroamérica obtained two values of a first value of $\mathrm{F}=2.5$ and a second value of 2.8 , Belmonte a value of $\mathrm{F}=2.2$ and Casa Real a value of $\mathrm{F}=2.3[63]$.

Other research was carried out in the community of West Golf in New Cairo, Egypt, where the sewerage system is configured as a combined sewerage system, although it rarely rains, this system collects wastewater to pump station that discharges a treatment plant that serves this community and other districts in the region and in order to know the maximum and minimum flows for the design of various components of the Wastewater Treatment Plant, WWTP, the actual peak factors were determined in 2014 to use more accurate critical flows. [4]. The calculation of these factors was based on 1 year of consecutive daily flow monitoring and was performed by the American University in Cairo, Egypt [4].

Similarly, in the city of Gadchiroli, located in India, Asian continent, a study was developed by the civil engineering department of the National Institute 
of Visvesvaraya Technology of Nagpur and which suggests a new methodology in which the peak factors are applied per node to the contributory population added in the access mouths, depending on the total contributor population, in the outlet sewer of that mouth of record [64].

As a result of the proposed methodology, the maximum effective peak factor is continuously reduced as the contributing population increases and these results were compared with those obtained using the Babbit and Harmon formulas, and it is observed that they provide slightly higher values for lower flows, however, this difference decreases as the contributing population increases, therefore the diameter and inclination of the collectors may not be greatly affected [64].

\section{Network management}

With the objective of analyzing the problems related to the design and construction of sewerage systems for residential areas, the American communities of Bradenton in Florida, Springfield in Missouri, Anaheim in California and Baltimore County in Maryland, with the support of the Department of Environmental Engineering Sciences at Johns Hopkins University, during the years 1959 to 1963 , they carried out an investigation, which allowed to identify that the flow of waters found in the times of rain, exceeded in some localities, up to twice the average flow of residual waters in dry time, this due to the bad construction of sewers generated the infiltration of underground waters and erroneous connections of drainage of rain waters [49].

Also in the majority of the evaluated places there were problems of obstruction in the collectors mainly by the intrusion of roots of trees and deposits of sediments of sands (soils without cohesion), this problematic was originated by the constructive system used, especially the mortar joints in the pipes, which have a minor resistance in comparison plastic joints [49].

There is also research developed with other more ambitious purposes at the level of wastewater management, such as the studies developed by the University of Arizona in the United States in 2005 and the University of the Andes in conjunction with the Water and Sewerage Company of the city of Bogota in Colombia in 2013.

The objective of the first case was to monitor sanitary sewer networks in order to identify the possibility of overflows in the system, called SSO (Sanitary Sewer overflow), which can be caused by a variety of causes including, but not limited to, blockages, breaks in sewer lines, severe weather conditions, incorrect operation and maintenance of the system, and vandalism. A methodology was established to locate flow meters in the network and be able to apply a complete hydraulic model for the sewer system, the County of Pima Arizona was used as a case study, then the flows were calculated under normal conditions, to begin to simulate different scenarios in the system and thus could identify three possible critical places in the network in which should be installed permanent flow meters for constant monitoring, which would facilitate the detection of these blockages and avoid overflows in the network [65].

In the second case, research was carried out based on seven years of monitoring and modelling to support the operation and development of the Bogotá (Colombia) wastewater system, in which the components evaluated were: (a) the database of collected flow and water quality found in the system, (b) Identification of wastewater pollution load generators, and (c) implementation of a sewerage network model that matched the information available from the two previous components. An operational model was constructed with a level of complexity scientifically justified but useful for the city of Bogotá to evaluate and manage the performance of the system and plan its development. More generally, the work demonstrated the value of monitoring and modeling programs that can be obtained through uncertainty and sensitivity analysis, as well as the applicability to growing megacities despite the computational and data costs that sophisticated contemporary high-resolution models of the sewerage system can generate [45].

As a complement to this research work, also in 2013 in the city of Bogota, a methodology was developed 
and evaluated to quantify the temporal and spatial variations of the input flows to the sewage system, in order to ensure the proper functioning of the expansion of the Salitre wastewater treatment plant and the construction of a new water treatment plant in the southeast of the city, for which it is necessary to understand the flow characteristics and water quality in the drainage system for dry and wet weather conditions. A stochastic model was implemented to determine the quantity and quality of water at the exit points of the sub-basins, where the treatment plants are located, from data collected since 2006 (24-hour time series), from a subsample of 29 sites selected from 150 available: also analyzed the existing variation in population density and time uses of the soil (residential, commercial, institutional or industrial), in the selected sub-basins and the general basins to which they belong [66].

It was found that the diurnal input patterns of the dry weather flow, called DWF (Dry Flow Weather Flow) can be modeled using Fourier series, these patterns are defined by a mean value and a set of multiplier factors per hour, evaluating series of $1^{\circ}, 2^{\circ}, 3^{\circ}$ and $4^{\circ}$ order, selecting series of 3 rd order to represent the time profiles. Finally, the possibility of transferring the methodology to other drainage systems was evaluated. The city of Linz (Austria) was evaluated as a case study [66].

Additionally, there are complementary stages or phases that can be developed around the variation of wastewater flows and peak factors. One of these stages consists of the development of hydraulic models based on field data and with the help of computer software that allows the evaluation and understanding of the behavior and operation of existing sewerage networks in a community; in Colombia, some studies focus on this evaluation phase as shown by the studies developed in the Medellín and Santa Marta networks.

In the Alcantarillado de Medellín Prado sector, research was focused to address a latent problem in hydraulic modeling, this problem lies at the time of generating a hydraulic model of a sewage system, since it is necessary that the results obtained are acceptably close to those presented in the prototype (reality). This research carried out by the University of Los Andes in 2005 developed a methodology of calibration of sewerage networks under nonpermanent flow with the use of Genetic Algorithms (GA) and EPASWMM software, hydraulic simulation engine, performing hydraulic calibration in networks of different topology, topography and hydraulic properties, finding high quality results where the parameter calibrated in the system was the relative roughness coefficient, evaluating the effectiveness of the results with the adjustment of the limnigrams measured in the prototype and simulated with the calibrated model [67].

Another case study carried out the "Modeling and hydraulic simulation of the sanitary sewer system of the Rodadero-Gaira district of Santa Marta, Colombia" developed by the University of Magdalena, Colombia, in 2015, with the purpose of establishing the hydraulic behavior of the system, for which flow gauges were made at the wastewater pumping station (WWPS) [68].

A hydraulic simulation in uniform flow was carried out for the hydraulic calculation with the help of the EPA SWMM V 5.0 Software, later the system was calibrated, allowing to simulate three scenarios of a stretch of the network with specific characteristics of operation (length of 659.6 meters and diameter of 12 inches). Scenario 1 allowed simulating the initial state of the system (original construction conditions) and it was possible to identify three sections working under pressure and with the possibility of overflows in the system. Scenario 2 evaluated the solution to the problem presented in the network, keeping the material (vitrified Sandstone) but increasing the diameter to 16 inches and Scenario 3 proposed another solution by maintaining the same diameter 12 ", but changing the material to Polyvinyl Chloride, PVC; In addition, the modeling allowed establishing that the sewerage network would be operating at a lower flow than the design, due to its high roughness coefficient, possible result of inadequate operation and maintenance of the networks, its age (more than 20 years) and the accelerated growth of the population served [68].

n South America in Chile, in 1999, a pilot project was developed to model sewage networks in the 
sector of the commune of Puente Alto, in the city of Santiago, with the aim of predetermining the most appropriate system for modeling sewage networks, using the software HIDROWORKS, MOUSE and other existing simulators. The modeling was based on the real information of the area under study, entering the simulators parameters that characterize it, such as: population, number of homes, drinking water consumption, type of surface runoff areas, sewage network with its elements and elevations. In addition, historical values were incorporated to measure sewage flows, carried out in the same area, with which the modeling was calibrated [51].

The result showed that modeling is feasible to perform and is a support tool for decision making in the stages of planning, evaluation and management of hydraulic behavior of any area under study, being essential to have a reliable database that meets all the characteristics of the area under study [51].

Also in European countries such as England, research has been carried out that includes hydraulic modeling of sewerage systems. In Edenbridge, southeast England, flow monitors were installed for approximately 4 months, of which 25 days corresponded to a dry period generating the average discharge flow curve in the system [69].

The collected data were incorporated into a developed computer model called FLUSH, in which several parameters were implemented (occupation, volume, duration and discharge) and pipe parameters such as (diameter, slope and material), friction resistance was modeled using the modified Colebrook-White equation for open channel flow, sewer connections at the mouths were modeled simply, as a function of continuity and local head losses [69].

An accurate representation of the flow regime at the top and bottom of the network was obtained as a result of the model, as well as the quantitative evaluation of the variability of the flow from day to day, also generated useful values in the design or analysis of the combined sewer overflow operation. It was concluded that the FLUSH model can also be used as a planning tool and useful in assessing and preventing demographic trends and their implications for wastewater flow in sewers and water networks [69].

\section{Conclusions}

The monitoring of wastewater is currently in constant evolution and growth, including important issues facing society today, such as the growth and development of cities, as well as the management of water resources, the latter being affected by ignoring in many cases how many are the real flows and the quality of wastewater discharged into the water bodies of our planet. Through the research carried out in different parts of the world we can identify alternatives in the existing methodologies for the analysis of drainage systems, it also offers us a more precise path towards the important elements to be evaluated in sewage systems and also to be able to establish reference values that allow us to make a critical comparison of the results that can be obtained in research in order to determine the real state of the functioning of urban drainage systems in the world.

It is remarkable the wide field of investigation derived from the residual waters and the systems of sewerage, as it is shown in this account there are several antecedents that when studying and knowing in depth the procedures employed in each one of the mentioned projects as state of the art, it is possible to define of a clearer and precise way the methodological strategies to employ, the techniques of more effective measurement, the equipment of monitoring more employed and the techniques of analysis of information to implement.

In conclusion, it is suggested as a research topic to implement instrumentation, monitoring and control systems that allow an adequate and permanent control of the drainage systems in Colombia to establish proper parameters for each system to clearly identify the behavior of incoming flows and the hours that represent the maximum and minimum discharges, due to the small number of investigations carried out in the country.

\section{References}

[1] N. Zambrano, "Ed., Recolección de aguas residuales, Primera. Popayán”, Leomine Editores, Universidad del Cauca, 2015.

[2] C. y T. C. Ministerio de Vivienda, 0330 - 2017. Pdf. 2017, pp. 182. 
[3] G. Balacco et al., "Evaluation of Peak Water Demand Factors in Puglia (Southern Italy)", Water, vol. 9, no. 2, pp. 96, 2017.

[4] E. H. Imam and H. Y. Elnakar, "Design flow factors for sewerage systems in small arid communities", Journal of Advanced Research, vol. 5, no. 5, pp. 537-542, 2014.

[5] ONU and CEPAL, “Agenda 2030 y los Objetivos de Desarrollo Sostenible Una oportunidad para América Latina y el Caribe", 2016.

[6] M. Zhang and S. She, "Wastewater Monitoring System in Industrial Workshop Based on Wireless Sensor Network", International Journal of Online and Biomedical Engineering, vol. 13, no. 3, pp. 63-74, 2017.

[7] S. Tan, Y. Hou, C. Cui, X. Chen and W. Li, "Real-time monitoring of biofoulants in a membrane bioreactor during saline wastewater treatment for anti-fouling strategies", Bioresource Technology, vol. 224, pp. 183187, 2017.

[8] Q. Guoxiu, Y. Xu, L. Wang, X. Zhang, W. Zhou and W. Li, "Design of an on-line monitoring system for radioactive wastewater", Journal of Radioanalytical and Nuclear Chemistry, vol. 314, no. 1, pp. 215-220, 2017.

[9] Y. Li, H. Jin, H. Li and J. Li, "Study on indicators for on-line monitoring and diagnosis of anaerobic digestion process of piggery wastewater", Environmental Technology \& Innovation, vol. 8, pp. 423430, 2017.

[10] J. Wang et al., "In situ monitoring of wastewater biofilm formation process via ultrasonic time domain reflectometry (UTDR)", Chemical Engineering Journal, vol. 334, pp. 2134-2141, 2018.

[11] L. Feng, W. Zhang and X. Li, "Monitoring of regional drug abuse through wastewater-based epidemiology-A critical review", Science China Earth Sciences, vol. 61, no. 3, pp. 239255, 2018.
[12] J. Wang, Z. Tian, Y. Huo, M. Yang, X. Zheng and Y. Zhang, "Monitoring of 943 organic micropollutants in wastewater from municipal wastewater treatment plants with secondary and advanced treatment processes", Journal of Environmental Sciences, vol. 67, pp. 309-317, 2018.

[13] G. Liu, J. Peng, H. Zheng and D. Yuan, "Developing on-site paper colorimetric monitoring technique for quick evaluating copper ion concentration in mineral wastewater", Spectrochimica Acta Parte A: Espectroscopía molecular y biomolecular, vol. 196, pp. 392-397, 2018.

[14] M. Ashfaq et al., "Monitoring and mass balance analysis of endocrine disrupting compounds and their transformation products in an anaerobic-anoxic-oxic wastewater treatment system in Xiamen, China", Chemosphere, vol. 204, pp. 170-177, 2018.

[15] H. Han, S. Zhu, J. Qiao and M. Guo, "Datadriven intelligent monitoring system for key variables in wastewater treatment process", Chinese Journal of Chemical Engineering, vol. 26, no. 10, pp. 2093-2101, 2018.

[16] K. Song et al., "High-rate partial nitrification of semiconductor wastewater: Implications of online monitoring and microbial community structure", Biochemical Engineering Journal, vol. 143, pp. 34-40, 2019.

[17] N. Fan, M. Yang, S. Rossetti, C. Levantesi and R. Qi, "Monitoring, isolation and characterization of Microthrix parvicella strains from a Chinese wastewater treatment plant", Water Science \& Technology, vol. 79, no. 7, pp. 1406-1416, 2019.

[18] L. C. Withrow, "Parameter correlation in wastewater dispersal area groundwater monitoring wells serving Corolla Light \#1 Wastewater Treatment Facility in Currituck County, North Carolina", Environmental Practice, vol. 19, no. 4, pp. 182-195, 2017.

[19] R. C. Trinh et al., “Application of Landsat 8 for Monitoring Impacts of Wastewater Discharge 
on Coastal Water Quality", Frontiers in Marine Science, vol. 4, 2017.

[20] M. Sgroi, P. Roccaro, G. V. Korshin and F. G. A. Vagliasindi, "Monitoring the Behavior of Emerging Contaminants in WastewaterImpacted Rivers Based on the Use of Fluorescence Excitation Emission Matrixes (EEM)", Environmental Science \& Technology, vol. 51, no. 8, pp. 4306-4316, 2017.

[21] M. Sgroi et al., "Use of fluorescence EEM to monitor the removal of emerging contaminants in full scale wastewater treatment plants", Journal of Hazardous Materials, vol. 323, pp. 367-376, 2017.

[22] M. Amarasiri, M. Kitajima, T. H. Nguyen, S. Okabe and D. Sano, "Bacteriophage removal efficiency as a validation and operational monitoring tool for virus reduction in wastewater reclamation: Review", Water Research, vol. 121, pp. 258-269, 2017.

[23] J. D. Mosley, D. R. Ekman, J. E. Cavallin, D. L. Villeneuve, G. T. Ankley and T. W. Collette, "High-resolution mass spectrometry of skin mucus for monitoring physiological impacts and contaminant biotransformation products in fathead minnows exposed to wastewater effluent", Environmental Toxicology and Chemistry, vol. 37, no. 3, pp. 788-796, 2018.

[24] C. G. Daughton, "Monitoring wastewater for assessing community health: Sewage ChemicalInformation Mining (SCIM)", Science of the Total Environment, vol. 619-620, pp. 748-764, 2018.

[25] H. R, "To monitor the health of cities residents, look no further than their sewers Wastewater is a fount of information about the drugs and other compounds communities consume", Chemical \& Engineering News, vol. 96, no. 18, pp. 30-35, 2018.

[26] Y. Huang et al., "Real-Time in Situ Monitoring of Nitrogen Dynamics in Wastewater Treatment Processes using Wireless, Solid-State, and IonSelective Membrane Sensors", Environmental Science \& Technology, vol. 53, no. 6, pp. 31403148, 2019.

[27] Sakari Toivakainen, Riku Kopra, H. Hannukainen and T. Laukkanen, "Monitoring dissolved COD in a pulp mill wastewater treatment plant by measuring total dissolved solids with a refractometer", APPITA Journal, vol. 70, no. 1, pp. 55-60, 2017.

[28] J. Tomperi, E. Koivuranta, A. Kuokkanen and K. Leiviskä, "Modelling effluent quality based on a real-time optical monitoring of the wastewater treatment process", Environmental Technology, vol. 38, no. 1, pp. 1-13, 2017.

[29] A. J. Rissanen, A. Ojala, T. Fred, J. Toivonen and M. Tiirola, "Methylophilaceae and Hyphomicrobium as target taxonomic groups in monitoring the function of methanolfed denitrification biofilters in municipal wastewater treatment plants", Journal of Industrial Microbiology and Biotechnology, vol. 44, no. 1, pp. 35-47, 2017.

[30] J. Tomperi, E. Koivuranta and K. Leiviskä, "Predicting the effluent quality of an industrial wastewater treatment plant by way of optical monitoring", Journal of Water Process Engineering, vol. 16, pp. 283-289, 2017. 